\title{
Aquatic Physical Therapy in the balance and gait of people with Parkinson's Disease: a pilot study
}

\author{
Fisioterapia Aquática no equilíbrio e marcha na pessoa com \\ Doença de Parkinson: estudo piloto
}

\section{Fisioterapia Acuática en equilibrio y marcha en persona con Enfermedad de Parkinson: estudio piloto}

\author{
Taina Christinelli ${ }^{1}$, Gabriella Ferreira ${ }^{2}$, Dielise Debona Iucksch ${ }^{3}$, \\ Juliana Siega4, Adriano Zanardi da Silva5, Bruna Yamaguchi ${ }^{6}$, \\ Vera Lúcia Israel $^{7}$
}

\begin{abstract}
1.Fisioterapeuta, graduada pelo Departamento de Prevenção e Reabilitação em Fisioterapia UFPR, Mestranda, Programa de Pós-Graduação em Educação Física, Universidade Federal do Paraná, CuritibaPR, Brasil. Orcid: https://orcid.org/0000-0001-6050-492X

2.Fisioterapeuta, graduada pelo Departamento de Prevenção e Reabilitação em Fisioterapia, Universidade Federal do Paraná, Curitiba-PR, Brasil. Orcid: https://orcid.org/0000-0003-3302-1775

3.Fisioterapeuta, Mestre, Doutoranda, Programa de Pós-Graduação em Educação Física, Universidade Federal do Paraná, Curitiba-PR, Brasil. Orcid: https://orcid.org/0000-0001-9362-5920

4.Fisioterapeuta, Mestre, Doutoranda, Programa de Pós-Graduação em Educação Física, Universidade Federal do Paraná, Curitiba-PR, Brasil. Orcid: https://orcid.org/0000-0001-7533-7781

5.Fisioterapeuta, Mestre, Doutorando, Programa de Pós-Graduação em Educação Física, Universidade Federal do Paraná, Curitiba-PR, Brasil. Orcid: https://orcid.org/0000-0003-2117-9049

6.Fisioterapeuta, Doutora, Programa de Pós-Graduação em Educação Física, Universidade Federal do Paraná, Curitiba-PR, Brasil. Orcid: https://orcid.org/0000-0003-1352-3399

7.Professora Doutora, Departamento de Prevenção e Reabilitação em Fisioterapia, Programa de PósGraduação em Educação Física, Universidade Federal do Paraná, Curitiba-PR, Brasil. Orcid: https://orcid.org/0000-0001-5824-7792
\end{abstract}

\begin{abstract}
Resumo
Introdução. A Doença de Parkinson (DP) é uma doença neurodegenerativa, crônica e progressiva, que ocorre principalmente devido à depleção de neurônios dopaminérgicos da substância negra. Caracteriza-se pelos sinais cardinais de bradicinesia, rigidez, tremor e instabilidade postural, que contribuem para déficits funcionais de equilíbrio corporal e na marcha. Dentro das possibilidades de intervenção, destaca-se a Fisioterapia Aquática (FA), atuante na prevenção e reabilitação de alterações motoras e funcionais, utilizando propriedades físicas e térmicas da água. Objetivo. Verificar os efeitos da FA sobre o equilíbrio corporal e marcha. Método. Trata-se de um estudo piloto, de uma pesquisa quaseexperimental, envolvendo um grupo com diagnóstico clínico de DP, que participou de um programa de FA, com duração de 12 semanas, 2 vezes por semana. Para avaliação foram utilizados: Mini BESTest para o equilíbrio corporal e Escala Dynamic Gait Index (DGI) para o equilíbrio durante a marcha. A análise estatística foi realizada utilizando o Statistical Package for the Social Sciences (SPSS). Resultados. Participaram do estudo 11 participantes, com média etária de $70,73 \pm 3,2$ anos. Após o programa de $F A$, verificou-se que não houve diferença significante no Mini BESTest $(p=0,41)$ e no DGI $(p=0,105)$. Conclusões. Concluiu-se que $o$ programa de FA proposto não foi capaz de apresentar melhora significante para o equilíbrio e marcha no grupo de indivíduos com DP em questão.
\end{abstract}

Unitermos. Doença de Parkinson; Equilíbrio Postural; Marcha; Hidroterapia; Fisioterapia

\footnotetext{
Abstract

Background. Parkinson's disease (PD) is a neurodegenerative, chronic, progressive disease, resulting mainly from the depletion of dopaminergic neurons in the substantia nigra. It is characterized by four cardinal signs, namely: bradykinesia, stiffness, tremor, and postural instability, which contribute to body balance and gait functional deficits. Among the possibilities
} 
of intervention, the Aquatic Physical Therapy (APT) stands out in the prevention and rehabilitation of motor and functional alterations, using water physical and thermal properties. Objective. To verify the effects of APT on body balance and gait. Method. This pilot study is part of quasi-experimental research involving a group with a clinical diagnosis of PD. They participated in an APT program for 12 weeks, twice a week. They were assessed with the MiniBESTest for body balance and the Dynamic Gait Index (DGI) for gait balance. The statistical analysis was made in the Statistical Package for the Social Sciences (SPSS). Results. A total of 11 people - mean age of $70.73 \pm 3.2$ years - participated in the study. After the APT program, no difference was verified in the Mini-BESTest $(p=0.41)$ or the DGI $(p=0.105)$. Conclusions. The APT program proposed was unable to present significant improvement regarding the balance and gait in the group of people with PD in question.

Keywords. Parkinson's disease; Postural Balance; Gait; Hydrotherapy; Physical Therapy

\title{
Resumen
}

Introducción. La enfermedad de Parkinson (EP) es una enfermedad neurodegenerativa, crónica y progresiva, que se produce principalmente por el agotamiento de las neuronas dopaminérgicas de la sustancia negra. Se caracteriza por signos cardinales de bradicinesia, rigidez, temblor e inestabilidad postural, que contribuyen a déficits funcionales en el equilibrio corporal y la marcha. Dentro de las posibilidades de intervención, destaca la Fisioterapia Acuática (FA), activa en la prevención y rehabilitación de alteraciones motoras y funcionales, utilizando las propiedades físicas y térmicas del agua. Objetivo. Verificar los efectos de la FA sobre el equilibrio corporal y la marcha. Método. Se trata de un estudio piloto, un estudio cuasi-experimental, que involucró a un grupo con diagnóstico clínico de EP, que participó en un programa de FA, de 12 semanas de duración, dos veces por semana. Para la evaluación, se utilizó lo siguiente: Mini BESTest para el equilibrio corporal y la Escala de índice de marcha dinámica (DGI) para el equilibrio durante la marcha. El análisis estadístico se realizó mediante el paquete estadístico para las ciencias sociales (SPSS). Resultados. Participaron del estudio

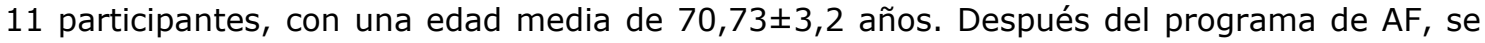
encontró que no hubo diferencia significante en Mini BESTest $(p=0.41)$ y en DGI $(p=0.105)$. Conclusiones. Se concluyó que el programa de FA propuesto no pudo presentar datos significativos para el equilibrio y la marcha en el grupo de personas con EP en cuestión.

Palabras clave. Enfermedad de Parkinson; Equilibrio postural; Marzo; Hidroterapia; Fisioterapia

Research developed at Universidade Federal do Paraná, Curitiba-PR, Brasil.

\section{INTRODUCTION}

\author{
Parkinson's disease (PD) is one of the movement \\ disorders that most affect older adults. It is caused by \\ progressive degeneration of the central nervous system \\ (CNS) mainly due to the death of dopamine-producing
} neurons in the substantia nigra ${ }^{1}$. This slowly progressing, chronic disease has an estimated prevalence of 
approximately 85 to 187 per 100 thousand people ${ }^{2}$, affecting mostly those 70 to 80 years old 3 . The characteristic motor signs in diagnosis are bradykinesia associated with other signs such as stiffness and tremor at rest, reinforced by the presence of postural instability as the disease progresses ${ }^{4}$.

With time, the person presents functional alterations in postural balance and, consequently, in gait ${ }^{5}$. The deficits in balance appear because of the motor impairments correlated with a certain inefficiency in processing vestibular, visual, and proprioceptive signs to perform the activities of daily living ${ }^{6}$. Hence, with the alteration in postural control and balance reactions, there is an increased risk of falls. Such a decline in motor capacity also contributes to a decrease in functional performance, including difficulties to perform daily tasks, besides negatively changing these individuals' quality of life ${ }^{7,8}$.

Gait is cortically and subcortically controlled in healthy people - the subcortical control is automatic and quick, whereas the cortical one is slow and sensitive to any other stimulus. In PD, the automatic control processes are dysfunctional due to the deficits in the functioning of the basal ganglia in the dopamine-dependent pathways ${ }^{9}$.

Other factors interfere with gait and postural balance, such as the stooped and inclined posture ${ }^{5}$ and frozen gait characterized as the incapacity to take the first step, or efficiently take steps in sequence ${ }^{10}$. Another alteration is the festinating gait, defined as rapid small steps with increasing pace which, in association with the alteration in the center of 
gravity, triggers such a pattern ${ }^{11}$.

There are no indicators that drug treatment alone is the most efficient. Therefore, multiprofessional attention must focus on $P D^{12}$. Thus, the ideal is that the strategies involving a physical therapy approach be aligned with adequate clinical prescription of therapeutic and functional exercises, which bring good results to the performance in physical aptitudes, body balance, and gait ${ }^{5,13}$.

The Aquatic Physical Therapy (APT) is one of the possibilities in the field of physical therapy, especially because it has physiological and thermal effects, such as muscle relaxation and decreased muscle spasms, which in turn influence the PD patients' stiffness and physical/motor tension ${ }^{5}$. These positive effects promote a tridimensional environment to perform exercises that make movements easier - such as body weight shift and postural adjustments in the changes in the center of gravity during dynamic gait movement in the aquatic environment - diminishing the risk of falls and the muscle pains ${ }^{5,14}$.

Hence, several motor features can be positively modified using APT on PD persons ${ }^{5,13}$. The aquatic environment is safe and has physiological and thermal effects for exercises on PD population. However, is not clear how much this affects gait and balance when assessed by usual evaluation scales. Therefore, this study aimed to verify the effects of APT on body balance and gait in people with PD. 


\section{METHOD}

\section{Sample}

This is a single-blinded (blind assessor) pilot study in quasi-experimental research, convenience sampling, in which participants with a clinical diagnosis of Parkinson's disease (PD) were invited to aquatic interventions and assessed before and after them. The research was approved by the Research Ethics Committee (REC), issued by the Department of Health Sciences at the Universidade Federal do Paraná, under CAAE: 66781417.4.0000.0102. Participants were recruited from the Paranaense Association of Parkinsionism and the intervention took place at the Ana Carolina Moura Xavier Rehabilitation Hospital, in Curitiba, Paraná, Brazil.

The participants met the following inclusion criteria: they were from both genders, attested clinical diagnosed with idiopathic PD, classified in stages 1 to 4 in Hoehn and Yahr scale, with a clinical certificate to attend aquatic physical activities in a heated pool.

The exclusion criteria, in their turn, were participants confined to a wheelchair (either due to PD or not), without independent gait, with another pathology that could cause vestibular or balance alterations, or with some deficit that impaired them from following instructions (such as visual or auditory deficits, keeping them from understanding verbal or visual commands), and that had either absolute or relative contraindications to attend a heated pool. Also, participants 
whose dosage of Levodopa changed during the research, who did not agree with or sign the informed consent form (ICF), or who gave up during the research were excluded from it.

\section{Procedures}

The static and dynamic body balance was assessed using the Mini-BESTest, an abbreviated version of the Balance Evaluation Systems Test (BESTest). The MiniBESTest was translated into Brazilian Portuguese and validated for an elderly population ${ }^{15,16}$. It encompasses the anticipatory balance, reactive postural control, sensory orientation, and dynamic gait domains. Hence, it simulates daily activities and even removes sensory information (such as sight) in some tasks to challenge balance. This test comprises 14 items, each scoring 0 to 2, with a summed total of 28 points - the lower the score, the worse is the body balance impairment ${ }^{15,16}$.

The Dynamic Gait Index (DGI) is used to assess balance while gait-related activities are being performed and has been translated and validated for Brazilian Portuguese ${ }^{17}$. It assesses gait performance in response to changes in demands and risk of fall, namely: gait in a level surface, change in gait speed, gait with horizontal and vertical head turns, gait and pivot turn, step over and around obstacles, step up and down the stairs. Each demand can be given a score from 0 to 3 according to the participants' performance; the maximum score is 24 points, which indicates the best 
performance. The lower the score, the greater the risk of falls ${ }^{17}$.

The Aquatic Physical Therapy (APT) intervention lasted 12 weeks, with twice-a-week, 40-minute sessions. Before and after each session, the vital signs (arterial pressure, cardiac frequency, and respiratory frequency) were measured. The APT program was proposed based on the phases of adaptation, specialized therapeutic exercises, and relaxation ${ }^{18}$. These phases encompass the participant's adaptation in the pool and gait training (e.g., gait with face immersion); strength training of flexor muscle, extensor muscle, abductor muscle, and adductor muscle of the hip; balance training (e.g., sit and stand); relaxation; cooling down (these last ones using $\mathrm{Ai}$ Chi movements - in each session, three of the movements in the method were used, with increasing difficulty). The intervention was designed and applied by a physical therapist, who did not participate in the assessments on land.

\section{Statistical Analysis}

Descriptive statistics were used to present the composition of the study sample, with the age being presented as mean and standard deviation. The other figures were presented as absolute numbers and percentage. The quantitative statistical analysis was conducted in the Statistical Package for the Social Sciences (SPSS 22). The variables were tested regarding normality with the ShapiroWilk test - when the normality was proved, the paired t-test 
was used; and for nonparametric data, the Wilcoxon test was used. Significant values were based on $p<0.05$.

\section{RESULTS}

A total of 11 participants with Parkinson's disease (PD) participated in the research. Their mean age was $70.73 \pm 3.22$ years, and they were classified in stages 2 (4 participants, 36,36 \%), stage 3 (3 participants, 27,27\%) and 4 (4 Participants, 36,36\%) in Hoehn and Yahr scale. In the sample, 7 (63.6\%) were men. During this phase of the study, there weren't dropouts.

The results for body balance assessment and reassessment values - in mean, standard deviation, 95\% confidence interval, maximum, minimum, and p-value obtained with the Mini-BESTest are described in Table 1 . No significant difference was found $(p=0.41)$.

Table 1. Comparison between the general and domain values obtained in the assessment before and after the intervention, using the Mini-BESTest.

\begin{tabular}{|c|c|c|c|c|}
\hline & & $\begin{array}{c}\text { ASSESSMENT } \\
\text { Mean } \pm \text { SD } \\
95 \% \text { confidence } \\
\text { interval } \\
\text { Minimum - maximum } \\
\text { values } \\
\end{array}$ & $\begin{array}{c}\text { REASSESSMENT } \\
\text { Mean } \pm \text { SD } \\
95 \% \text { confidence } \\
\text { interval } \\
\text { Minimum - maximum } \\
\text { values } \\
\end{array}$ & $\begin{array}{c}P \\
\text { value }\end{array}$ \\
\hline General & Total Mini-BESTest & $\begin{array}{c}21.18 \pm 3.89 \\
18.56-23.79 \\
16-27\end{array}$ & $\begin{array}{c}22 \pm 2.79 \\
20.12-23.87 \\
18-26\end{array}$ & 0.41 \\
\hline \multirow[t]{4}{*}{ Domains } & Anticipatory & $\begin{array}{c}4.36 \pm 1.02 \\
3.67-5.05 \\
3-6\end{array}$ & $\begin{array}{c}4.36 \pm 1.02 \\
3.67-5.05 \\
3-6\end{array}$ & 1 \\
\hline & $\begin{array}{ll}\text { Reactive } & \text { Postural } \\
\text { Control } & \end{array}$ & $\begin{array}{c}4.09 \pm 1.64 \\
2.98-5.19 \\
1-6\end{array}$ & $\begin{array}{c}3.9 \pm 1.22 \\
3.08-4.72 \\
2-6\end{array}$ & 0.6 \\
\hline & Sensory Orientation & $\begin{array}{c}5.63 \pm 0.5 \\
5.29-5.97 \\
5-6\end{array}$ & $\begin{array}{c}5.18 \pm 0.75 \\
4.67-5.6 \\
4-6\end{array}$ & $0.02 *$ \\
\hline & Dynamic Gait & $\begin{array}{c}7 \pm 1.48 \\
6-7.99 \\
4-9\end{array}$ & $\begin{array}{c}8 \pm 1.68 \\
7.22-9.49 \\
4-10\end{array}$ & 0.08 \\
\hline
\end{tabular}


The results of the Mini-BESTest were also stratified according to the domains encompassed in the scale: the anticipatory $(p=1.0)$, reactive postural control $(p=0.6)$, sensory orientation $(p=0.02)$, and dynamic gait $(p=0.08)$. A significant difference was revealed $(p<0.05)$ in sensory orientation - which tests static balance with eyes opened in a stable surface, and with eyes closed in two unstable surfaces (foam and ramp).

The mean score obtained in the DGI was 20.7 points in the assessment and 22.09 in the reassessment. There was an improvement, although without a significant difference $(p=0.105)$, of $6.71 \%$. The characteristics of this variable are described in Figure 1 in median and interquartile ranges of $25-75 \%$ of the nonparametric data.

Figure 1. Comparative chart of the gait assessments (DGI).

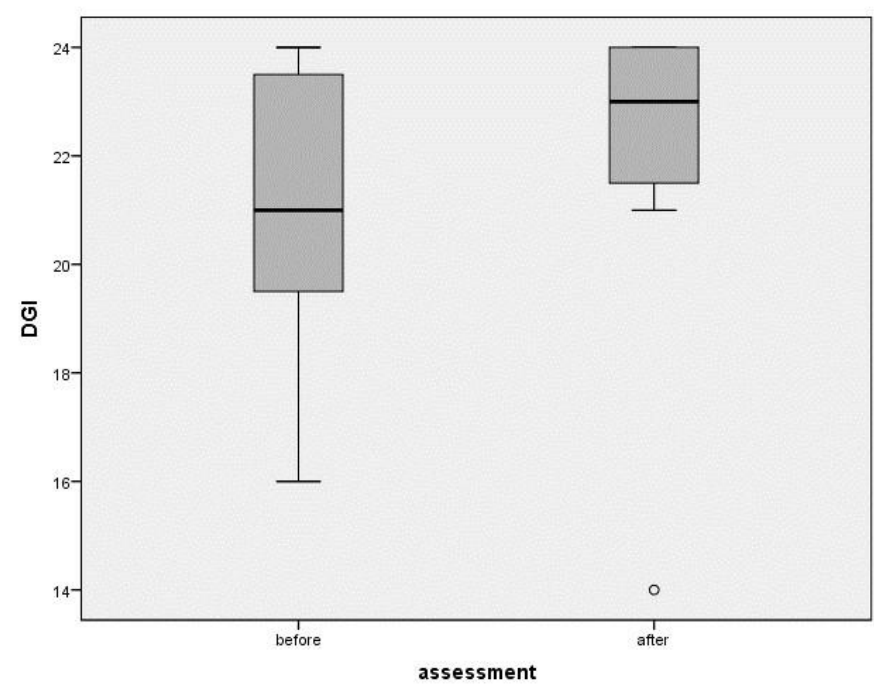

Shapiro-Wilk test. 


\section{DISCUSSION}

The absence of significant results in body balance is the opposite of what was found in studies cited in a literature review $^{19}$. In it, this variable was assessed with the Berg Balance Scale (BBS), Tinetti, and Mini-BESTest, revealing improvements ${ }^{19}$.

Other study also had a significant improvement in balance (assessed with BBS) after APT intervention ${ }^{20}$. The authors even verified that APT exercises were more effective than conventional land therapy for the balance of people with $P D$. One of the points that can explain the difference in the present study's results, besides the scale used, is that the protocol was dedicated to balance disturbance exercises, administered five days a week, for two months - whereas the present study, in addition to balance, focused on adaptation to the aquatic environment, gait, strength, and relaxation.

Hence, the aquatic environment can potentially furnish balance gains by stimulating the torso movements and displacement, in all planes, from the center of mass to beyond the support base, with more safety than on a land environment ${ }^{11}$. It should be mentioned that, even with the water properties acting upon the individuals, it is investigated whether the external stimulation from the resistance to water favors a modulation in proprioceptive afferents. Thus, it demonstrates that the aquatic environment can increase the proprioceptive information to the immersed body, leading to better body alignment and 
producing beneficial effects on postural control and balance ${ }^{21}$.

However, in this body balance assessment instrument, the relevant measure to indicate clinical changes - called Minimum Clinically Important Difference (MCID) - is four points $^{22,23}$. Hence, although the MCID was not significant either, in this study two participants' (18.2\% of the sample) individual means reached the value.

Furthermore, the cutoff score for the risk of falls in PD is 20 points in the Mini-BESTest ${ }^{16}$. The data analysis shows that the mean score is above this value; also, individually, five participants ( $45.5 \%$ of the population studied) had values above the cutoff in the assessment and maintained them in the reassessment. Since it is a progressive pathology, sustaining such values is positive. Moreover, three participants ( $27.3 \%$ of the sample) who did not reach the cutoff in the assessment, reached beyond 20 points in the reassessment.

With the DGI, even increasing two points in the median, raising the minimum value from 19 to 21 , and 1.39 in the mean value, the result was not significant. Nevertheless, attention is called to the high values obtained even in the pretest, near the maximum achievable value in this scale ${ }^{24}$. In the study conducted with older adults, it is proposed that 2.9 points be increased in the DGI to represent a $95 \%$ confidence that there was an actual change in the person's function ${ }^{24}$. Regarding the people with PD, the authors of the 
present study have not found MDC-related data for the DGI so far.

Furthermore, on the DGI, the participants maintained a score above 19, a value considered the limit for risk of falls in individuals with $\mathrm{PD}^{25}$. This can indicate that the aquatic intervention had a positive effect on body balance during the participants' gait. Hence, it is reckoned that the APT was effective in maintaining the participants' functional mobility, as in the study in which, despite not having a significant difference in the result, the group maintained a low percentage of participants with functional incapacity/high risk of falls ${ }^{26}$.

A study assessed the gait performance in people with PD. It compared an experimental group - which participated in an aquatic intervention with 32 fifty-minute sessions of functional exercises - with a control group. The experimental group improved the gait speed after the intervention, evidencing the effects of the aquatic physical therapy in this regard ${ }^{13}$.

The buoyancy, density, hydrostatic pressure, and viscosity incite strategies of cortical voluntary movements, improving the performance of body movements and activities $^{20}$. Considering that the water viscosity slows movements down, avoiding potential falls, this process provides more time to recover and adjust body posture.

Thus, the statement is reinforced that the improvements in body balance and gait can be explained using the physical and thermal properties of the heated pool 
- e.g., the density, buoyancy, hydrostatic pressure, viscosity, and thermal properties ${ }^{20}$. The physical properties of the aquatic environment change the human movement patterns and furnish to the person new motor and sensory experiences ${ }^{27}$.

The aquatic environment reduces apparent body weight due to the Archimedes' principle - i.e., when the water surface is in the level of the hip the hydrostatic weight decreases $46 \%$ on average, while in the level of the xiphoid process it decreases approximately $70 \%{ }^{28}$. Therefore, the aquatic environment improves movement through resistance (flows, density, hydrostatic pressure, and buoyancy) and support (relative density, hydrostatic pressure, and buoyancy). The muscle activity increases in walking, while the buoyancy enables movements with reduced submerged weight. Thus, the subaquatic environment allows for active mobilization and dynamic strengthening ${ }^{29}$.

The therapeutic physical exercises and the physical and thermal properties of water influence and help the gait, giving the person confidence to perform activities in the pool. Likewise, buoyancy offers support, making the person even more confident and easing their fear of falling 27 . A study analyzed subaquatic gait and revealed that in water the step is shortened, the pace is reduced, and the speed is slowed down. Also, these decreased gait parameters were associated with the increased angular displacements of the hip and shoulder joints ${ }^{28}$. 
This study was limited by low number of participants as well as the absence of a control group. It is suggested, then, that future studies analyze the effects of aquatic physical therapy exercises approaching a larger sample size.

\section{CONCLUSIONS}

It is concluded that the proposed Aquatic Physical Therapy program did not produce significant gains in this group of people with Parkinson's disease.

\section{ACKNOWLEDGEMENTS}

This study was financed in part by the Coordenação de Aperfeiçoamento de Pessoal de Nível Superior - Brasil (CAPES) - Finance Code 001.

\section{REFERENCES}

1.Armstrong MJ, Okun MS. Diagnosis and treatment of Parkinson disease: a review. Jama 2020;323:548-60. http://dx.doi.org/10.1001/jama.2019.22360

2. Musial P, Michalik M, Nowak E, Szefler-derela J. The influence of the 6-month course of nordic walking on patient with Parkinson's disease - a case report. Central Eur J Sport Sci Med 2017;20:31-8. http://dx.doi.org/10.18276/cej.2017.4-04

3. Abbas MM, Xu Z, Tan LC. Epidemiology of Parkinson's disease east versus west. Mov Disord Clin Pract 2018;5:14-28. http://dx.doi.org/10.1002/mdc3.12568

4.Postuma RB, Berg D, Stern M, Poewe W, Olanow W, Oertel W, et al. Clinical Diagnostic Criteria for Parkinson's Disease. Mov Disord 2015;30:1591-601. http://dx.doi.org/10.1002/mds.26424

5. Costa PS, Bôas ECCV, Fonseca EP. Efetividade do treino de marcha na água para pacientes com doença de parkinson: revisão sistemática. Rev Pesq Fisio Salvador 2018;8:551-7. http://dx.doi.org/10.17267/2238-2704rpf.v8i4.2034

6.Sveinbjornsdottir S. The clinical symptoms of Parkinson's disease. J Neurochem 2016;139:318-24. http://dx.doi.org/10.1111/jnc.13691

7.Winser SJ, Kannan P, Bello UM, Whitney SL. Measures of balance and falls risk prediction in people with Parkinson's disease: a systematic 
review of psychometric properties. Clin Rehabil 2019;33:1949-62. http://dx.doi.org/10.1177/0269215519877498

8.Santos SM, da Silva RA, Terra MB, Almeida IA, de Melo LB, Ferraz $\mathrm{HB}$. Balance versus resistance training on postural control in patients with Parkinson's disease: a randomized controlled trial. Eur J Phys Rehabil Med 2017;53:173-83. http://dx.doi.org/10.23736/S19739087.16.04313-6

9.Debû B, Godeiro CDO, Lino JC, Moro E. Managing gait, balance, and posture in Parkinson's disease. Curr Neurol Neurosci Reports 2018;18:23. http://dx.doi.org/10.1007/s11910-018-0828-4

10. Weiss D, Schoellmann A, Fox MD, Bohnen NI, Factor SA, Nieuwboer $A$, et al. Freezing of gait: understanding the complexity of an enigmatic phenomenon. Brain 2020;143:14-30.

http://dx.doi.org/10.1093/brain/awz314

11. Mirelman A, Bonato P, Camicioli R, Ellis TD, Giladi N, Hamilton JL, et al. Gait impairments in Parkinson's disease. Lancet Neurol 2019;18:697-708. http://dx.doi.org/10.1016/S1474-4422(19)300444

12.Yamaguchi B, Ferreira MP, Israel VL. A multidisciplinaridade na redução da levodopa na pessoa com doença de Parkinson avançada. Acta Fisiátrica 2016;23:4. http://dx.doi.org/10.5935/01047795.20160037

13.Yamaguchi B, Ferreira MP, Israel VL. Aquatic Physiotherapy and Parkinson's Disease: Effects on Functional Motor Skills. Adv Parkinsons Dis 2020;9:1. http://dx.doi.org/10.4236/apd.2020.91001

14.Lobato LD, Dias JM. A Eficácia da Terapia Aquática em Pacientes com Doença de Parkinson. Rev Eletr Estácio Saúde 2015;4. http://revistaadmmade.estacio.br/index.php/saudesantacatarina

15. Maia AC, Rodrigues-de-Paula F, Magalhães LC, Teixeira R L. Crosscultural adaptation and analysis of the psychometric properties of the Balance Evaluation Systems Test and MiniBESTest in the elderly and individuals with Parkinson's disease: application of the Rasch model. Braz J Phys Ther 2013;17:195-217. http://dx.doi.org/10.1590/S141335552012005000085

16.Leddy $A L$, Crowner BE, Earhart GM. Utility of the Mini-BESTest, BESTest, and BESTest sections for balance assessments in individuals with Parkinson disease. J Neurol Phys Ther 2011;35:90. http://dx.doi.org/10.1097/NPT.0b013e31821a620c

17. Castro SM, Perracini MR, Ganança FF. Versão Brasileira do Dynamic Gait Index. Rev Bras Otorrinolaringol 2006;72:817-25. http://dx.doi.org/10.1590/S0034-72992006000600014

18. Israel VL, Pardo MBL. Hidroterapia: proposta de um programa de ensino no trabalho com lesado medular em piscina térmica. Fisioter Mov 2000;13:111-27.

https://pesquisa.bvsalud.org/portal/resource/pt/lil-108885

19. Masiero S, Maghini I, Mantovani ME, Bakdounes L, Koutsikos K, Del Felice $A$, et al. Is the aquatic thermal environment a suitable place for providing rehabilitative treatment for person with Parkinson's disease? 
A retrospective study. Inter J Biometeorol 2018:1-6. http://dx.doi.org/10.1007/s00484-018-1632-1

20.Volpe D, Giantin MG, Maestri R, Frazzitta G. Comparing the effects of hydrotherapy and land-based therapy on balance in patients with Parkinson's disease: a randomized controlled pilot study. Clin Rehabil 2014:1-8. http://dx.doi.org/10.1177/0269215514536060

21.Volpe D, Giantin MG, Manuela P, Filippetto C, Pelosin E, Abbruzzese $\mathrm{G}$, et al. Water-based vs. non-water-based physiotherapy for rehabilitation of postural deformities in Parkinson's disease: a randomized controlled pilot study. Clin Rehabil 2017;31:1107-15. http://dx.doi.org/10.1177/0269215516664122

22. Cook CE. Clinimetrics corner: the minimal clinically important change score (MCID): a necessary pretense. J Manual Manipul Ther 2008;16:82E-3. http://dx.doi.org/10.1179/jmt.2008.16.4.82E

23.Godi M, Franchignoni F, Caligari M, Giordano A, Turcato AM, Nardone A. Comparison of reliability, validity, and responsiveness of the mini-BESTest and Berg Balance Scale in patients with balance disorders. Phys Ther 2013;93:158-67. http://dx.doi.org/10.2522/ptj.20120171

24.Romero S, Bishop MD, Velozo CA, Light K. Minimum Detectable Change of the Berg Balance Scale and Dynamic Gait Index in Older Persons at Risk for Falling. J Geriatr Phys Ther 2011;34:131-7. http://dx.doi.org/10.1519/JPT.0b013e3182048006

25.Keus S, Munneke M, Graziano M, Paltamaa J, Pelosin E, Domingos J, et al. European Physiotherapy Guideline for Parkinson's Disease. The Netherlands:

KNGF/ParkinsonNet,

2014. https://www.parkinsonnet.nl/app/uploads/sites/3/2019/11/eu guideli ne parkinson development and justification.pdf

26.Silva AZ, Israel VL. Effects of dual-task aquatic exercises on functional mobility, balance and gait of individuals with Parkinson's disease: A randomized clinical trial with a 3-month follow-up. Compl Ther Med 2018;42:119-24. http://dx.doi.org/10.1016/j.ctim.2018.10.023

27.Iucksch DD, Araujo LB, Novakoski KRM, Yamaguchi B, Carneiro CF, Mélo TR, et al. Decoding the aquatic motor behavior: description and reflection on the functional movement. Acta Scientiarum Health Sci 2020;42:e47129.http://dx.doi.org/10.4025/actascihealthsci.v42i1.47 129

28. Harrison R, Bulstrode S. Percentage weight-bearing during partial immersion in the hydrotherapy pool. Physiother Pract 1987;3:60-3. http://dx.doi.org/10.3109/09593988709087741

29.Volpe D, Morris M, Guiotto A, Iansek R, Frazzitta G, Sawacha Z. Underwater gait analysis in Parkinson's disease. Gait Posture 2015;42:8. http://dx.doi.org/10.1016/j.gaitpost.2015.03.149 